\title{
Economic costs of extratropical storms under climate change: An application of FUND
}

\author{
Daiju Narita ${ }^{1}$, Richard S.J. Tol $^{2}$, David Anthoff ${ }^{3}$
}

\begin{abstract}
Extratropical cyclones have attracted some attention in climate policy circles as a possible significant damage factor of climate change. This study conducts an assessment of economic impacts of increased storm activities under climate change with the integrated assessment model FUND 3.4. In the base case, the direct economic damage of enhanced storms due to climate change amounts to $\$ 2.4$ billion globally (approximately $35 \%$ of the total economic loss of storms at present) at the year 2100 , while its ratio to the world GDP is $0.0007 \%$. The paper also shows various sensitivity runs exhibiting up to 4 times the level of damage relative to the base run.
\end{abstract}

Corresponding Author: Email: daiju.narita@ifw-kiel.de

\footnotetext{
${ }^{1}$ Kiel Institute for the World Economy, Düsternbrooker Weg 120, Kiel 24105, Germany

${ }^{2}$ Economic and Social Research Institute, Whitaker Square, Sir John Rogerson's Quay, Dublin 2, Ireland; Email: richard.tol@esri.ie

Institute for Environmental Studies and Department of Spatial Economics, Vrije Universiteit, De Boelelaan 1081, Amsterdam, the Netherlands

Department of Engineering and Public Policy, Carnegie Mellon University, Baker Hall 129, Pittsburgh, PA 15213, USA

${ }^{3}$ Economic and Social Research Institute, Whitaker Square, Sir John Rogerson's Quay, Dublin 2, Ireland; Email: david.anthoff@esri.ie
}

ESRI working papers represent un-refereed work-in-progress by members who are solely responsible for the content and any views expressed therein. Any comments on these papers will be welcome and should be sent to the author(s) by email. Papers may be downloaded for personal use only. 


\section{Economic costs of extratropical storms under climate change: An application of FUND}

\section{Introduction}

The increase of atmospheric greenhouse gases may change the global climate system in multiple ways, among which is the pattern of storm incidence. Storms are at the top list of the costliest events in Europe for the insurance industry (e.g., Reinhard, 2005), and the largest storms could make tangible economic loss even at a national scale. Along with tropical cyclones (Narita et al., 2008), extratropical storms have also attracted the attention of various people in the context of climate change, especially because a number of large-sized events took place in Europe in recent decades (e.g., Dorland et al., 1999; Reinhard, 2005).

Generally speaking, such large extratropical storms are not frequent, and the economic impacts of storms are thus on average not very profound, at least in rich countries (Dorland et al., 1999). However, global climate change might alter the picture. The reinsurance industry (e.g., Swiss Re, 2006) has found that the economic costs of severe storm events have expanded over the last several decades, one of the drivers for which might be climate change. As climate changes further in the future, storm damages might become a more important factor even in the richest economies in the midlatitudes, not to mention lower income economies in the same latitudinal zones.

Climatologists have not yet reached a consensus on future changes in activities of extratropical cyclones under climate change, but it would be safe to say that the enhancement of extratropical storm damage under climate change is recognized as a conceivable case. In fact, some of the well-accepted findings on this topic, the ones documented in IPCC Assessment Reports, are consistent with the claim. First, the IPCC Fourth Assessment Report (2007) indicates that it is likely that there has been a net increase of extratropical cyclones in frequency or intensity over the Northern Hemispheric land since 1950, although mechanisms other than climate change (e.g., decadal-scale fluctuations) could explain the change as well. Second, both IPCC's Third and Fourth Assessment Reports $(2001,2007)$ introduce, though not endorse, the view that the number of intense extratropical cyclones may increase under climate change (whereas the total number of storms might be reduced), citing a set of research works 
reaching this conclusion (e.g., Lambert and Fyfe, 2005). Third, the Fourth Assessment Report describes that the "consistent" results from different general circulation models show a poleward shift of storm tracks as a result of climate change, in other words, greater storm activities at high latitudes.

Some efforts have been made as to include extratropical storms in integrated assessment models on climate change. For example, in a European context, a number of papers assess a possible increase of economic loss due to extratropical storms under climate change (e.g., Dorland et al., Leckebusch et al., 2007, Pinto et al., 2007, Hanson et al., 2004). Leckebusch et al. (2007) conduct regressions of daily maximum wind speeds (calculated with multiple general circulation models (GCMs)) with recorded property losses, and they conclude that storm-related economic loss in the UK and Germany would increase up to $37 \%$. Pinto et al. (2007) apply a similar method to Western Europe by using a single GCM (ECHAM5/MPI-OM1) and estimate that the change of the mean annual loss of storms is in the range from $-4 \%$ to $43 \%$ in the case of Germany. Hanson et al. (2004) estimate the future economic impact of storms in the UK with climate change. In addition to insurance losses, Hanson et al. discuss the forestry sector in detail, using a model incorporating the strength of the stem and the resistance of the tree to overturning. Meanwhile, Dorland et al. (1999) draw on local data of property damage from a winter storm hit the Netherlands in 1990 (Daria). They derive an exponential relationship between the damage and the maximum wind speed and conclude that "an increase of $2 \%$ in wind intensity by the year 2015 could lead to a $50 \%$ increase in storm damage... only $20 \%$ of the increase is due to population and economic growth."

To our knowledge, however, no previous study of economic modelling discussed this topic in a global context, and placed in the context of the total economic impact of climate change. In a global study of economic impacts of storms and climate change, one additional consideration needed in analysis would be the effects of income levels, which are very different across countries. Two factors are in play with regard to the relationship between affluence and disaster damages (e.g., Toya and Skidmore, 2007): economic damages of natural disasters may be magnified in richer economies because a unit amount of loss in capital leads to a bigger loss of income due to high 
productivity of capital; on the other hand, the wealthy can insulate themselves from disasters.

In this paper, we discuss long-term economic effects of extratropical cyclones with climate change computed by the integrated assessment model FUND 3.4. Extratropical storms are a new element in FUND. In the following, brief descriptions of FUND and our approach to model the damage of extratropical cyclones are presented in Section 2. Section 3 shows the results. Section 4 concludes.

\section{Methodology: Estimation of extratropical cyclone impacts with FUND}

\subsection{The FUND model}

We use Version 3.4 of the Climate Framework for Uncertainty, Negotiation and Distribution (FUND) for our analysis of climate change impacts with enhancement of tropical cyclone activities. Version 3.4 of FUND has the same basic structure as that of Version 1.6, which is described and applied by Tol (1999, 2001, 2002c). Except for the extratropical storm component which is discussed in this paper, the impact module of the model is outlined and assessed by Tol $(2002 \mathrm{a}, \mathrm{b})$. The latest publication using the FUND platform is Anthoff et al. (2009). The source code and a complete description of the model can be found at http://www.fund-model.org/.

Essentially, FUND is a model that calculates damages of climate change for 16 regions of the world listed in Table 1 by making use of exogenous scenarios of socioeconomic variables. The scenarios comprise of projected temporal profiles of population growth, economic growth, autonomous energy efficiency improvements and carbon efficiency improvements (decarbonisation), emissions of carbon dioxide from land use change, and emissions of methane and of nitrous oxide. Carbon dioxide emissions from fossil fuel combustion are computed endogenously on the basis of the Kaya identity. The calculated impacts of climate change perturb the default paths of population and economic outputs corresponding to the exogenous scenarios. The model runs from 1950 to 3000 in time steps of a year, though the outputs for the 1950-2000 period is only used for calibration, and the years beyond 2100 are used for the approximating the social cost of carbon under low discount rates, a matter that does not 
concern us in this paper. The scenarios up to the year 2100 are based on the EMF14 Standardized Scenario, which lies somewhere in between IS92a and IS92f (Leggett et al., 1992). For the years from 2100 onward, the values are extrapolated from the pre2100 scenarios. The radiative forcing of carbon dioxide and other greenhouse gases used by FUND is determined based on Shine et al. (1990). The global mean temperature is governed by a geometric build-up to its equilibrium (determined by the radiative forcing) with a half-life of 50 years. In the base case, the global mean temperature increases by $2.5^{\circ} \mathrm{C}$ in equilibrium for a doubling of carbon dioxide equivalents. Regional temperature increases, which are the primary determinant of regional climate change damages (except for tropical cyclones, as discussed below), are calculated from the global mean temperature change multiplied by a regional fixed factor, whose set is estimated by averaging the spatial patterns of 14 GCMs (Mendelsohn et al., 2000).

As described by Tol (2002a), the model considers the damage of climate change for the following categories besides tropical cyclones: agriculture, forestry, water resources, sea level rise, energy consumption, unmanaged ecosystems, and human health (diarrhoea, vector-borne diseases, and cardiovascular and respiratory disorders). In our version of FUND, tropical cyclones are treated as a separate category, rather than as a factor elevating damage levels of existing categories (e.g., crop damages from enhanced floods). Impacts of climate change can be attributed to either the rate of temperature change (benchmarked at $0.04^{\circ} \mathrm{C}$ per year) or the level of temperature change (benchmarked at $1.0^{\circ} \mathrm{C}$ ). Damages associated with the rate of temperature change gradually fade because of adaptation.

FUND also has macroeconomic and policy components. Reduced economic output due to damages of climate change is translated into lower investment (with exogenous saving rates) and consequently slower growth rates. With policy variables such as those representing carbon abatement measures, FUND can be operated as an assessment tool for long-run climate policy. In this paper, however, we do not use this policy-assessment function of the model. 


\subsection{Extratropical cyclones}

We model extratropical cyclones with the FUND framework similarly in spirit to the modelling of hurricane impacts (see Narita et al., 2008). The economic damage due to an increase in the intensity of extratropical storms follows the equation below:

$$
\frac{E T D_{t, r}}{Y_{t, r}}=\alpha_{r}\left(\frac{y_{t, r}}{y_{1990, r}}\right)^{\varepsilon} \delta_{\text {hemisphere }}\left(\frac{C_{C O 2, t}}{C_{C O 2, p r e}}\right)^{\gamma}
$$

$E T D_{t, r}$ and $Y_{t, r}$ are the damage due to extratropical cyclones (increase relative to preindustrial) and GDP in region $r$ and time $t$, respectively. Note that Equation (1) represents the effect of a deviation of extratropical cyclones from its pre-industrial (i.e., not the total level of storm damages). $\alpha_{r}$ is the factor determining the benchmark level of cyclone damages for region $r$ (see Table 2). The data for cyclone damages are drawn from the Emergency Events Database (EM-DAT: http://www.emdat.be/) by the WHO Collaborating Centre for Research on the Epidemiology of Disasters (CRED). The CRED EM-DAT is an international initiative which assembles and organizes the data of natural disaster damages collected by various institutions worldwide (i.e., UN organizations, governments, NGOs, universities, private firms, and the press). The database contains basic data on the occurrence and the effects of more than 17,000 disasters in the world from 1900 to the present (Scheuren et al., 2008). Although the dataset has the weakness that its economic damage data are listed on a reported basis from different institutions and lack consistency, it is more comprehensive than other similar types of dataset and thus the best available at present. The coefficient $\alpha_{r}$ is estimated by averaging storm damages in the dataset over the period 1986-2005. It should be noted that storm impacts vary greatly year to year, and the level of the coefficient is extremely sensitive to what period is chosen and averaged. We address this issue by conducting a set of sensitivity runs, which are discussed in the next section.

The component $\left(y_{t, r} / y_{1990, r}\right)^{\varepsilon}$ in Equation (1) represents the effect of income level on vulnerability to storms, where $y$ is per capita income (in 1995 US\$ per year) in region $r$ at time $t$. Two factors are in play with regard to the relationship between 
affluence and disaster damages: economic damages of natural disasters may be magnified in richer economies because a unit amount of loss in capital leads to a bigger loss of income due to high productivity of capital; on the other hand, their wealth can insulate themselves from disaster damages by defensive expenditure or expensive but better infrastructure resistant to disaster shocks. In Equation (1), $\varepsilon$ is the income elasticity of storm damage and set at -0.514 (standard deviation: 0.027 ) after Toya and Skidmore (2007).

$\delta_{\text {hemisphere }}$ is a parameter indicating how much the number of intense storms increases. $C_{C O 2, t}$ is the atmospheric $\mathrm{CO}_{2}$ concentrations; $C_{C O 2}$, pre is the $\mathrm{CO}_{2}$ concentrations in the pre-industrial era. The levels of parameter are set based on Lambert and Fyfe's (2005) comparison exercise of 15 GCMs with regard to atmospheric $\mathrm{CO}_{2}$ concentrations and global incidence of storms. They showed that a majority of GCMs show an increase in the number of intense storms (i.e., storms whose pressure is lower than $970 \mathrm{mb}$ at the central grid point) with higher $\mathrm{CO}_{2}$ concentrations, whereas the total number of storms generally declines. Their results also reveal that the sensitivity of intense storm occurrence to $\mathrm{CO}_{2}$ increases is generally greater in the Southern Hemisphere than in the Northern Hemisphere. For our study, we set the levels of $\delta_{\text {hemisphere }}$ to their estimated representative numbers from the GCM results, showing that the number of intense storms would increase by $8 \%$ and $42 \%$ with a doubling of $\mathrm{CO}_{2}$ in the northern and southern hemispheres, respectively. ${ }^{4}$ We assume that only intense storms would cause substantial damage. Since Lambert and Fyfe's study only documents hemispheric estimates, we simply averaged the numbers of the Northern and Southern Hemispheres for the regions straddling the two hemispheres (i.e., SAM, SAS, SEA, and SIS). As a result of the above, we set the parameter $\delta_{\text {hemisphere }}$ as follows: $\delta_{N H}=0.04$ (applicable to USA, WEU, JPK, EEU, FSU, MDE, CAM, CHI, and NAF); $\delta_{S H}=0.21$ (applicable to ANZ); $\delta_{\text {Straddling }}=\left(\delta_{N H}+\delta_{S H}\right) / 2=0.13$ (applicable to SAM, SAS, SEA, and SIS). In the standard run, we adopt the simple assumption that the damage has a linear relationship with the $\mathrm{CO}_{2}$ concentrations (i.e., $\gamma=1$ ). In sensitivity runs, we investigate the significance of this linear assumption with different levels of $\gamma$.

\footnotetext{
${ }^{4}$ We use the representative numbers from Lambert and Fyfe's "1ppcto2x" scenario runs. The scenario is that $\mathrm{CO} 2$ concentrations are gradually increased from the pre-industrial level to the doubled over about 70 years and then held constant. The values of $\delta$ are calculated by averaging the enhancement of storm occurrence at the time when concentrations hit the doubled level (years 61-80) and of long-run levels (years 201-220).
} 
Similar to the rest of the impact module for FUND (Tol, 2002a; Narita et al., 2008), the extratropical cyclone component has a separate function estimating mortality in addition to that for economic damages:

$$
\frac{E T M_{t, r}}{P_{t, r}}=\beta_{r}\left(\frac{y_{t, r}}{y_{1990, r}}\right)^{\eta} \delta_{h}\left(\frac{C_{C O 2, t}}{C_{C O 2, p r e}}\right)^{\gamma}
$$

In Equation (2), ETM $M_{t, r}$ and $P_{t, r}$ are the mortality due to extratropical cyclones (increase relative to pre-industrial) and the population in region $\mathrm{r}$ and time $\mathrm{t}$, respectively. $\beta_{r}$ signifies the regional baseline level of mortality from tropical cyclones (based on the CRED EM-DAT data, see Table 2). $\eta$ is the income elasticity of storm damage and set as -0.501 (standard deviation: 0.051) after Toya and Skidmore (2007). The number of death computed after the equation is translated into loss of population. The mortality is also considered to be equivalent with some economic loss: as in the other impact categories in FUND, mortality due to tropical cyclones is valued at 200 times the per capita income of the affected region. This is set to be consistent with the discussion by Cline (1992), who drew on average annual wage data and estimates of the value of a statistical life.

\section{Results}

Table 3 summarizes the results for the economic damage and mortality of extratropical storms in the year 2100. The results represent increased damages relative to preindustrial times (i.e., without climate change). In the base case, the extra direct economic damage from climate change enhanced storms amounts to $\$ 2.4$ billion (1995 US dollar per year). This figure is approximately $35 \%$ of the expected global total economic storm damage in 2005 (\$7 billion) - that is, climate change would increase winter storm damage by about one-third. It is about one eighth of the enhanced tropical cyclone damage for the same year calculated by FUND with the base assumptions $(\$ 19$ billion). The table also shows that intensified storms would cause 200 additional deaths (whose monetized value of life is $\$ 0.5$ billion) in the year 2100 in the base case. The 
increase of global temperature $\left(+3.2^{\circ} \mathrm{C}\right.$ above the pre-industrial level) causes economic damage, but the size of damage is also a reflection of the expanded size of the economy at 2100 , which is almost 8 times the 2000 level. The time trends of increased direct economic loss and its share to world GDP (for the base case: 1986-2005 baseline) presented in Figure 1 show this income effect more visibly. The graph shows a rapid increase of absolute storm damages, ${ }^{5}$ while the ratio of increased damage to GDP is more or less flat over the period, which is around $0.0007 \%$.

Table 3 also shows the results of sensitivity runs. As already mentioned, storm damages exhibit significant interannual variability, and the choice of baseline period affects the results. As alternative cases, we both extend and shorten the averaging period by ten years (1976-2005 and 1996-2005). As Table 3 shows, the direct economic damage is largest in the case of the original 1986-2005 baseline and smallest in the case of the 1996-2005 baseline. Storm damage is highest with the base years 1986-2005 because of the record storms in Western Europe in the year 1990 ( $\$ 15$ billion according to the EM-DAT data). The difference among the different sets of baseline is not very strong with regard to mortality because of the advanced warning systems and strict building standards in rich countries.

Figure 2 shows the regional disaggregation of damages (direct economic loss) for selected regions where storm impacts have relatively high economic significance (namely the USA, Canada, Western Europe and Australia and New Zealand). Figure 2 shows that Western Europe tops in terms of the absolute level of storm damage, with an amount over $\$ 0.3$ billion. On the other hand, Australia and New Zealand (ANZ) exhibits by far the highest damage relative to GDP, over $0.006 \%$ of GDP.

The other sets of results shown in Table 3 are sensitivity analyses for different values of parameters. The income elasticities of storm damage with regard to direct economic loss and mortality $(\varepsilon$ and $\eta$ ) are increased and decreased according to the standard deviations estimated by Toya and Skidmore (2007). As for the income elasticity on direct economic loss $(\varepsilon)$, the shift of level has a relatively small impact on outcome, by around $10 \%$ at most. The change in elasticity brings about a slightly larger change in mortality, up to around $15 \%$ of the total.

\footnotetext{
${ }^{5}$ In other words, the effect of climate change on storm damage is much less than $35 \%$ of total at present.
} 
Table 3 also shows the results of sensitivity runs with regard to $\delta$. We set the high and low $\delta$ s to be consistent with the upper and lower bounds in Lambert and Fyfe's comparison (from their Figure 7: this means $\delta_{N H}=0.17, \delta_{S H}=0.49$, and $\delta_{\text {Straddling }}=0.33$ for the high $\delta$ case, and $\delta_{N H}=-0.05, \delta_{S H}=0$, and $\delta_{\text {Straddling }}=-0.02$ for the low $\delta$ case). The last set of data listed in Table 3 varies the exponent $\gamma$, namely, $\gamma=3,2,0.5$. Note that parameter $\delta$ involves the change in frequency of intense storms, not in wind speed. While storm damage is more than linear in wind speed (e.g., Emanuel, 2005), it is probably linear in storm frequency. The sensitivity runs on $\delta$ and $\gamma$ show that higher levels of these parameters indeed lead to greater damages up to 4 times relative the base run's, but not in order of magnitude.

Figure 3 shows the increased damages of extratropical storms as a fraction of the total costs of climate change. Data represent the base results for the year 2100, and they are presented as ratios to both the gross (i.e., only damages are considered) and net (both benefits and damages are summed) total impacts. While some regions exhibit relatively strong contribution of extratropical storms on total damage in Figure 3 (e.g., Canada on the net basis), the graph does not indicate any clear, systematic patterns because gross and net total damages are very different in all regions in the first place. Table 4 shows the global marginal costs of carbon emissions calculated by FUND for the base case. The results presented are simple sums over the world regions. The results show that in a relative sense, the marginal costs from storm damages are negligible in the total marginal costs, and are even significantly less than the ones for tropical storms (about one tenth in case of the $0 \%$ time preference; cf. Narita et al., 2008).

\section{Discussion and conclusion}

This study estimates the economic impacts of enhanced storm activities under climate change with the integrated assessment model FUND 3.4. In the base case, the direct economic damage of enhanced storms due to climate change amounts to \$2.4 billion globally (approximately $35 \%$ of the total economic loss of storms at present) at the year 2100 , while the ratio to the world GDP is $0.0007 \%$.

The regional results (Figure 2) indicate that the economic effect of extratropical storms with climate change would have relatively minor importance for the US: The 
enhanced extratropical storm damage (less than $0.001 \%$ of GDP for the base case) is one order of magnitude lower than the tropical cyclone damage (roughly $0.01 \%$ GDP) calculated by the same version of FUND. In the regions without strong tropical cyclone influence, such as Western Europe and Australia and New Zealand, the extratropical storms might have some more significance as a possible damage factor of climate change. Especially for the latter, the direct economic damage could amount to more than $0.006 \%$ of GDP. Still, the impact is small relative to the income growth expected in these regions. ${ }^{6}$

Our assessment falls in the range of existing estimates on Europe. Leckebusch et al. (2007) concluded that in the UK and Germany, storm-related loss would increase by up to $37 \%$ under climate change (i.e., the change to be seen in the late $21^{\text {st }}$ century from the present). Pinto et al. (2007) showed that the change of the mean annual loss of storms is in the range from $-4 \%$ to $43 \%$ in the case of Germany. Meanwhile, Hanson et al. (2004) estimated no significant change in storm activities in the UK until the late $21^{\text {st }}$ century.

This study's results show different damage than Dorland et al. (1999), who assume an increase of wind intensity. They concluded that a $2 \%$ increase of wind intensity could lead to a $50 \%$ increase of storm loss in the Netherlands. Our study does not base its assessment on wind speed (whose global comparison data do not exist in the context of climate change), and thus these two sets of results are not directly comparable. However, their conclusion suggests that our estimates might be rather conservative.

This paper is an initial attempt to assess global impacts of extratropical storms under climate change, and it unavoidably has some limitations. The most important one would be the state of scientific knowledge it stands on, which is still somehow elusive and does not allow us to make detailed formulations of storm impacts for the model. Additionally, the following could be pointed out as limitations concerning our assessment approach itself. First, our computation adopted exogenous savings rates to simulate long-run growth paths with intensifying storms, but more accurate modelling would require endogenous decision functions of investment representing detailed

\footnotetext{
${ }^{6}$ This is about the baseline change and not about temporal variability of incidence, and of course, the latter variability factor might justify stronger institutions against storm damage. However, this issue is beyond scope of this paper.
} 
features of individual savings decisions in face of storms. Second, the model calculated damages of extratropical cyclones in making use of a separate component in the impact module in favour of analytical clarity and simplicity, but this means that the model ignores some combined effects of enhanced cyclones with other factors, such as its coupling effect with sea level rise.

\section{Acknowledgements}

Financial support by the US Environmental Protection Agency and the German Research Foundation (the "Future Ocean" Cluster of Excellence program) is gratefully acknowledged. 


\section{References}

Anthoff, D., C. Hepburn, and R.S.J. Tol, 2009. Equity weighting and the marginal damage costs of climate change, Ecological economics, 68(3), 836-849.

Cline, W.R., 1992. The economics of global warming, Institute for International Economics, Washington D.C.

Dorland, C., R.S.J. Tol, and J.P. Palutikof, 1999. Vulnerability of the Netherlands and northwest Europe to storm damage under climate change, Climatic change, 43, 513-535.

Emanuel, K., 2005. Increasing destructiveness of tropical cyclones over the past 30 years, Nature, 436, 686-688.

Hanson, C.E., Holt, T., and J.P. Palutikof, 2004. An integrated assessment of the potential for change in storm activity over Europe: Implications for insurance and forestry in the UK, IT1.4 final report, Tyndall Centre for Climate Change Research, February 2004.

IPCC, 2007. IPCC fourth assessment report.

IPCC, 2001. IPCC third assessment report.

Lambert, S.J. and J.C. Fyfe, 2005. Changes and frequencies and strengths simulated in enhanced greenhouse warming experiments: Results from the models participating in the IPCC diagnostic exercise, Climate dynamics, 26, 713-728.

Leckebusch, G., U. Ulbrich, L. Fröhlich, and J.G. Pinto, 2007. Property loss potentials for European midlatitude storms in a changing climate, Geophysical research letters, 34 , L05703, Doi: 10.1029/2006GL027663. 
Leggett, J., Pepper, W.J., and Swart, R.J., 1992. Emission scenarios for the IPCC: An Update, In: Houghton, J.T., Callander, B.A., Varney, S.K. eds., Climate change 1992 The supplementary report to the IPCC scientific assessment, Cambridge University Press.

Mendelsohn, R., W. Morrison, M.E. Schlesinger, and N.G. Andronova, 2000. Countryspecific market impacts of climate change, Climatic change, 45, 553-569.

Narita, D., R.S.J., Tol, and D. Anthoff, 2008. Damage costs of climate change through intensification of tropical cyclone activities: An application of FUND, ESRI Working Paper 259.

Pinto, J.G., E.L. Fröhlich, G.C. Leckebusch, and U. Ulbrich, 2007. Changing European storm loss potentials under modified climate conditions according to ensemble simulations of the ECHAM5/MPI-OM1 GCM, Natural hazards and earth system sciences, 7, 165-175.

Reinhard, J., 2005. Good data - The be-all and end-all for underwrites, in Weather catastrophes and climate change - Is there still hope for us? Munich Re.

Scheuren J.-M., O. le Polain de Waroux, R. Below, D. Guha-Sapir, and S. Ponserre, 2008. Annual disaster statistical review: The numbers and trends 2007, CRED, Brussels.

Shine, K.P., Derwent, R.G., Wuebbles, D.J., and Morcrette, J.-J., 1990. Radiative forcing of climate, In: Houghton, J.T., Jenkins, G.J., and Ephraums, J.J. eds. Climate change - The IPCC scientific assessment, Cambridge University Press.

Swiss Re, 2006. The effect of climate change: storm damage in Europe on the rise, Focus report. 
Tol, R.S.J., 1999. The marginal costs of greenhouse gas emissions, The energy journal, 20(1), 61-81.

Tol, R.S.J., 2001. Equitable cost-benefit analysis of climate change policies, Ecological economics, 36, 71-85.

Tol, R.S.J., 2002a. Estimates of the damage costs of climate change - Part I: Benchmark estimates, Environmental and resource economics, 21, 47-73.

Tol, R.S.J., 2002b. Estimates of the damage costs of climate change - Part II: Dynamic estimates, Environmental and resource economics, 21, 135-160.

Tol, R.S.J., 2002c. Welfare specifications and optimal control of climate change: An application of FUND, Energy Economics, 24, 367-376.

Toya, H., and M. Skidmore, 2007. Economic development and the impacts of natural disasters, Economics letters, 94, 20-25. 
Table 1. Regions considered in FUND

\begin{tabular}{|c|c|c|}
\hline Acronym & Name & Countries \\
\hline USA & USA & United States of America \\
\hline CAN & Canada & Canada \\
\hline WEU & $\begin{array}{l}\text { Western } \\
\text { Europe }\end{array}$ & $\begin{array}{l}\text { Andorra, Austria, Belgium, Cyprus, Denmark, Finland, France, } \\
\text { Germany, Greece, Iceland, Ireland, Italy, Liechtenstein, } \\
\text { Luxembourg, Malta, Monaco, Netherlands, Norway, Portugal, San } \\
\text { Marino, Spain, Sweden, Switzerland, United Kingdom }\end{array}$ \\
\hline JPK & $\begin{array}{l}\text { Japan and } \\
\text { South Korea }\end{array}$ & Japan, South Korea \\
\hline ANZ & $\begin{array}{l}\text { Australia and } \\
\text { New Zealand }\end{array}$ & Australia, New Zealand \\
\hline EEU & $\begin{array}{l}\text { Central and } \\
\text { Eastern } \\
\text { Europe }\end{array}$ & $\begin{array}{l}\text { Albania, Bosnia and Herzegovina, Bulgaria, Croatia, Czech } \\
\text { Republic, Hungary, FYR Macedonia, Poland, Romania, Slovakia, } \\
\text { Slovenia, Yugoslavia }\end{array}$ \\
\hline FSU & $\begin{array}{l}\text { Former } \\
\text { Soviet Union }\end{array}$ & $\begin{array}{l}\text { Armenia, Azerbaijan, Belarus, Estonia, Georgia, Kazakhstan, } \\
\text { Kyrgyzstan, Latvia, Lithuania, Moldova, Russia, Tajikistan, } \\
\text { Turkmenistan, Ukraine, Uzbekistan }\end{array}$ \\
\hline MDE & Middle East & $\begin{array}{l}\text { Bahrain, Iran, Iraq, Israel, Jordan, Kuwait, Lebanon, Oman, Qatar, } \\
\text { Saudi Arabia, Syria, Turkey, United Arab Emirates, West Bank and } \\
\text { Gaza, Yemen }\end{array}$ \\
\hline CAM & $\begin{array}{l}\text { Central } \\
\text { America }\end{array}$ & $\begin{array}{l}\text { Belize, Costa Rica, El Salvador, Guatemala, Honduras, Mexico, } \\
\text { Nicaragua, Panama }\end{array}$ \\
\hline SAM & $\begin{array}{l}\text { South } \\
\text { America }\end{array}$ & $\begin{array}{l}\text { Argentina, Bolivia, Brazil, Chile, Colombia, French Guiana, } \\
\text { Guyana, Paraguay, Peru, Suriname, Uruguay, Venezuela }\end{array}$ \\
\hline SAS & South Asia & Afghanistan, Bangladesh, Bhutan, India, Nepal, Pakistan, Sri Lanka \\
\hline SEA & $\begin{array}{l}\text { Southeast } \\
\text { Asia }\end{array}$ & $\begin{array}{l}\text { Brunei, Cambodia, East Timor, Indonesia, Laos, Malaysia, } \\
\text { Myanmar, Papua New Guinea, Philippines, Singapore, Taiwan, } \\
\text { Thailand, Vietnam }\end{array}$ \\
\hline $\mathrm{CHI}$ & China plus & China, Hong Kong, North Korea, Macau, Mongolia \\
\hline NAF & North Africa & Algeria, Egypt, Libya, Morocco, Tunisia, Western Sahara \\
\hline SSA & $\begin{array}{l}\text { Sub-Saharan } \\
\text { Africa }\end{array}$ & $\begin{array}{l}\text { Angola, Benin, Botswana, Burkina Faso, Burundi, Cameroon, Cape } \\
\text { Verde, Central African Republic, Chad, Congo-Brazzaville, } \\
\text { Congo-Kinshasa, Cote d'Ivoire, Djibouti, Equatorial Guinea, } \\
\text { Eritrea, Ethiopia, Gabon, Gambia, Ghana, Guinea, Guinea- Bissau, } \\
\text { Kenya, Lesotho, Liberia, Madagascar, Malawi, Mauritania, } \\
\text { Mozambique, Namibia, Niger, Nigeria, Rwanda, Senegal, Sierra } \\
\text { Leone, Somalia, South Africa, Sudan, Swaziland, Tanzania, Togo, } \\
\text { Uganda, Zambia, Zimbabwe }\end{array}$ \\
\hline SIS & $\begin{array}{l}\text { Small Island } \\
\text { States }\end{array}$ & $\begin{array}{l}\text { Antigua and Barbuda, Aruba, Bahamas, Barbados, Bermuda, } \\
\text { Comoros, Cuba, Dominica, Dominican Republic, Fiji, French } \\
\text { Polynesia, Grenada, Guadeloupe, Haiti, Jamaica, Kiribati, } \\
\text { Maldives, Marshall Islands, Martinique, Mauritius, Micronesia, } \\
\text { Nauru, Netherlands Antilles, New Caledonia, Palau, Puerto Rico, } \\
\text { Reunion, Samoa, Sao Tome and Principe, Seychelles, Solomon } \\
\text { Islands, St Kitts and Nevis, St Lucia, St Vincent and Grenadines, } \\
\text { Tonga, Trinidad and Tobago, Tuvalu, Vanuatu, Virgin Islands }\end{array}$ \\
\hline
\end{tabular}


Table 2. Baseline impact of tropical cyclones on property (direct economic damage) and mortality (based on 1986-2005 averages of the CRED EM-DAT data)

\begin{tabular}{lccccc}
\hline & \multicolumn{2}{c}{ Direct economic damage } & & \multicolumn{2}{c}{ Mortality } \\
\cline { 2 - 3 } \cline { 5 - 6 } & $\begin{array}{c}\text { Loss in } \\
\text { \$billion }\end{array}$ & $\begin{array}{c}\alpha_{\mathrm{r}} \\
(\% \text { of } \\
\text { GDP })\end{array}$ & & $\begin{array}{c}\text { Number of } \\
\text { casualties }\end{array}$ & $\begin{array}{c}\beta_{\mathrm{r}} \\
\text { per } \\
\text { million } \\
\text { people) }\end{array}$ \\
\hline USA & 1.1 & 0.012 & & 78 & 0.29 \\
CAN & 0.53 & 0.017 & & 20 & $6.3 \mathrm{E}-02$ \\
WEU & 2.5 & 0.021 & & 58 & 0.12 \\
JPK & 0.19 & $1.0 \mathrm{E}-03$ & & 57 & 0.11 \\
ANZ & 0.20 & 0.028 & & 5.1 & 0.12 \\
EEU & 0.20 & $4.6 \mathrm{E}-03$ & & 13 & 0.050 \\
FSU & 0.064 & $4.4 \mathrm{E}-03$ & & 44 & 0.13 \\
MDE & 0.031 & $1.6 \mathrm{E}-03$ & & 27 & 0.053 \\
CAM & 0.25 & $4.4 \mathrm{E}-03$ & & 55 & 0.13 \\
SAM & 0.021 & $3.6 \mathrm{E}-04$ & & 26 & 0.047 \\
SAS & 1.4 & 0.055 & & 263 & 0.20 \\
SEA & 0.15 & 0.006 & & 65 & 0.086 \\
CHI & 0.18 & 0.017 & & 138 & 0.11 \\
NAF & $1.0 \mathrm{E}-03$ & $2.8 \mathrm{E}-05$ & 15 & 0.038 \\
SSA & $1.8 \mathrm{E}-03$ & 0.055 & 31 & 0.20 \\
SIS & 0.51 & 0.043 & 156 & 1.6 \\
\hline
\end{tabular}


Table 3. Increased economic damage and mortality of extratropical cyclones in the year 2100 calculated by FUND

\begin{tabular}{|c|c|c|c|c|c|c|c|c|c|c|}
\hline \multirow[b]{2}{*}{ Cases } & \multirow[b]{2}{*}{ Baseline } & \multirow[b]{2}{*}{$\varepsilon$} & \multirow[b]{2}{*}{$\eta$} & \multirow[b]{2}{*}{$\gamma$} & \multicolumn{2}{|c|}{ Direct economic damage } & \multicolumn{2}{|c|}{ Mortality } & \multirow[b]{2}{*}{$\begin{array}{c}\text { Total } \\
\text { economic } \\
\text { damage } \\
\text { (\$billion) }\end{array}$} & \multirow[b]{2}{*}{$\begin{array}{l}\% \text { of } \\
\text { world } \\
\text { GDP }\end{array}$} \\
\hline & & & & & $\begin{array}{l}\text { Increase } \\
\text { from pre- } \\
\text { industrial } \\
\text { (\$ billion) }\end{array}$ & $\begin{array}{l}\text { Ratio to } \\
\text { world } \\
\text { GDP (\%) }\end{array}$ & $\begin{array}{c}\text { Increased } \\
\text { number of } \\
\text { death (from } \\
\text { pre- } \\
\text { industrial) }\end{array}$ & $\begin{array}{c}\text { Value of } \\
\text { lost life (\$ } \\
\text { billion, } \\
\text { increase } \\
\text { from pre- } \\
\text { industrial) }\end{array}$ & & \\
\hline \multirow[t]{3}{*}{ Base } & $\begin{array}{l}1986- \\
2005\end{array}$ & -0.514 & -0.501 & 1 & 2.4 & 0.0007 & 100 & 0.5 & 2.9 & 0.0009 \\
\hline & $\begin{array}{l}1976- \\
2005\end{array}$ & -0.514 & -0.501 & 1 & 1.8 & 0.0005 & 111 & 0.6 & 2.4 & 0.0007 \\
\hline & $\begin{array}{l}1996- \\
2005\end{array}$ & -0.514 & -0.501 & 1 & 0.9 & 0.0003 & 75 & 0.4 & 1.3 & 0.0004 \\
\hline $\begin{array}{l}\text { High } \varepsilon \\
\text { and } \eta\end{array}$ & $\begin{array}{l}1986- \\
2005\end{array}$ & -0.487 & -0.450 & 1 & 2.6 & 0.0008 & 115 & 0.5 & 3.1 & 0.0009 \\
\hline $\begin{array}{l}\text { Low } \varepsilon \\
\text { and } \eta\end{array}$ & $\begin{array}{l}1986- \\
2005\end{array}$ & -0.541 & -0.552 & 1 & 2.3 & 0.0007 & 87 & 0.4 & 2.7 & 0.0008 \\
\hline $\operatorname{High} \delta^{(a)}$ & $\begin{array}{l}1986- \\
2005\end{array}$ & -0.514 & -0.501 & 1 & 8.2 & 0.0024 & 308 & 1.7 & 9.9 & 0.0030 \\
\hline Low $\delta^{(\mathrm{b})}$ & $\begin{array}{l}1986- \\
2005\end{array}$ & -0.514 & -0.501 & 1 & -1.7 & -0.0005 & -50 & -0.4 & -2.1 & -0.0006 \\
\hline$\gamma=3$ & $\begin{array}{l}1986- \\
2005\end{array}$ & -0.514 & -0.501 & 3 & 9.6 & 0.0029 & 409 & 1.8 & 11.4 & 0.0034 \\
\hline$\gamma=2$ & $\begin{array}{l}1986- \\
2005\end{array}$ & -0.514 & -0.501 & 2 & 5.5 & 0.0016 & 232 & 1.1 & 6.6 & 0.0020 \\
\hline$\gamma=0.5$ & $\begin{array}{l}1986- \\
2005\end{array}$ & -0.514 & -0.501 & 0.5 & 1.1 & 0.0003 & 47 & 0.2 & 1.4 & 0.0004 \\
\hline
\end{tabular}

(a), (b): See text for the assumptions for those runs 
Table 4. Global marginal costs of $\mathrm{CO}_{2}$ emissions in $\$ \mathrm{tC}$ (the base case, simple sum for the world regions)

\begin{tabular}{lccc}
\hline & \multicolumn{3}{c}{ Pure rate of time preference } \\
\cline { 2 - 4 } & $0 \%$ & $1 \%$ & $3 \%$ \\
\hline Total & 109 & 9 & -3 \\
Extratropical storms & 0.03 & 0.01 & 0.01 \\
\hline
\end{tabular}




\section{Figure captions}

Figure 1. Time trends of increased direct economic loss of extratropical cyclones and its share to the world GDP

Figure 2. Increased direct economic loss (a) and its share to GDP (b) at the year 2100 for selected regions (results for the three different baseline sets are shown)

Figure 3. Increased direct economic damage of extratropical storms due to climate change as a fraction of the gross (i.e., only damages are considered) and net (both benefits and damages are summed) total costs of climate change for selected regions (at the year 2100 for the base case) 
Figure 1.

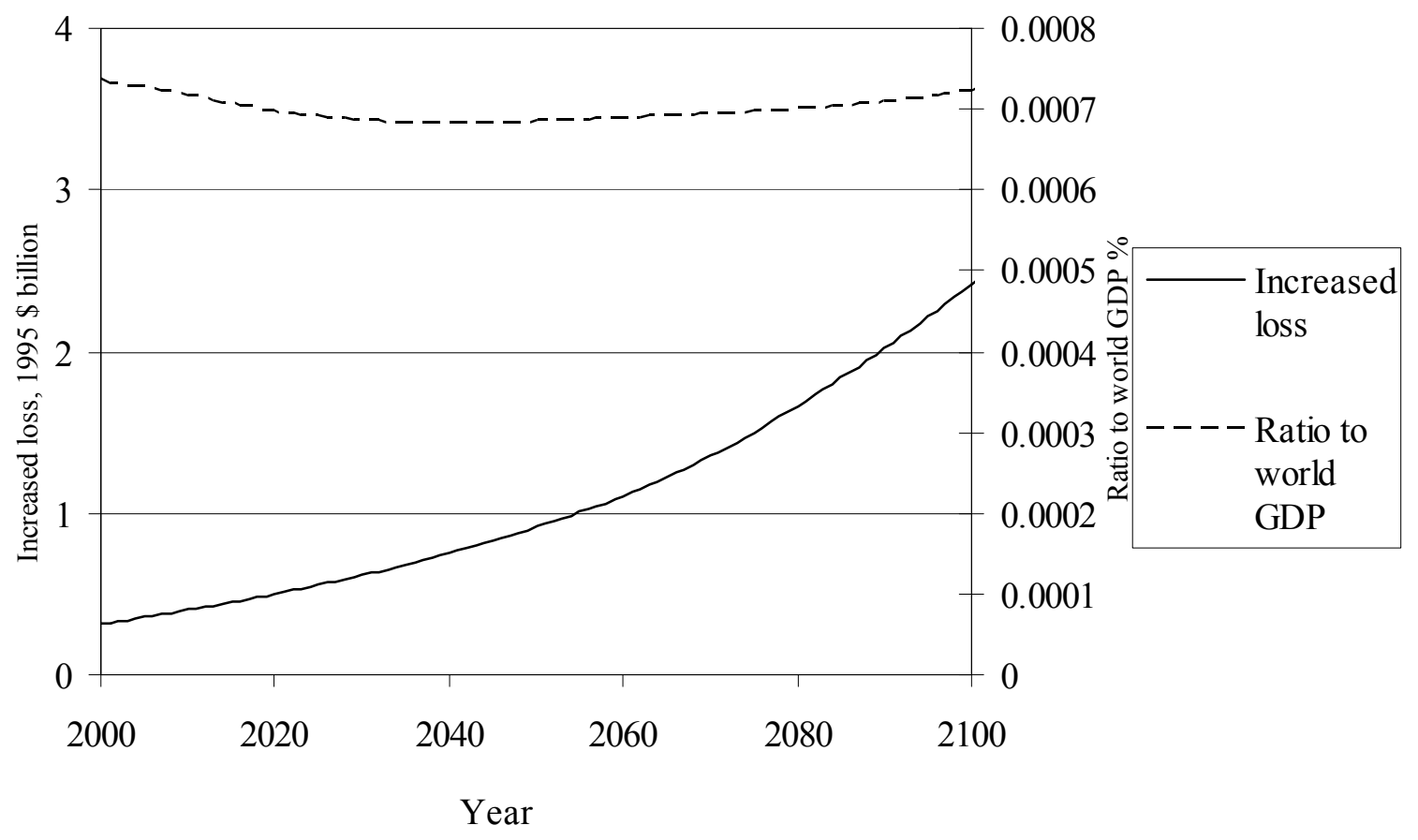


Figure 2.

a.

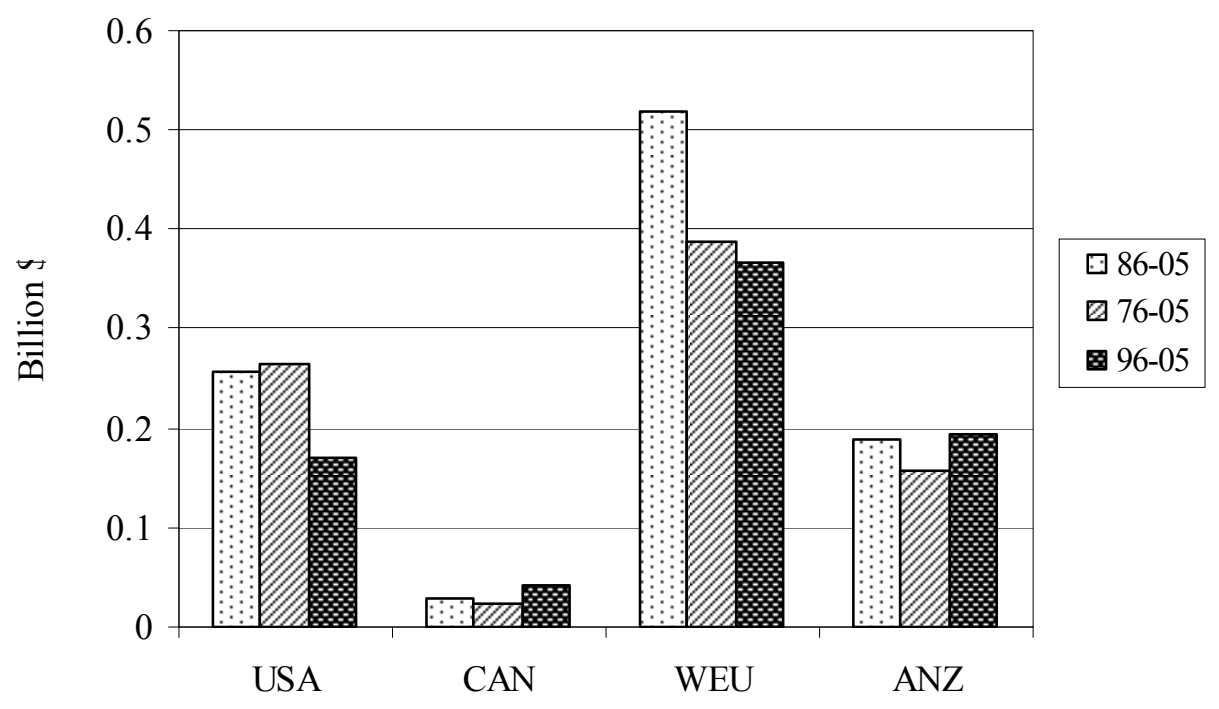

b.

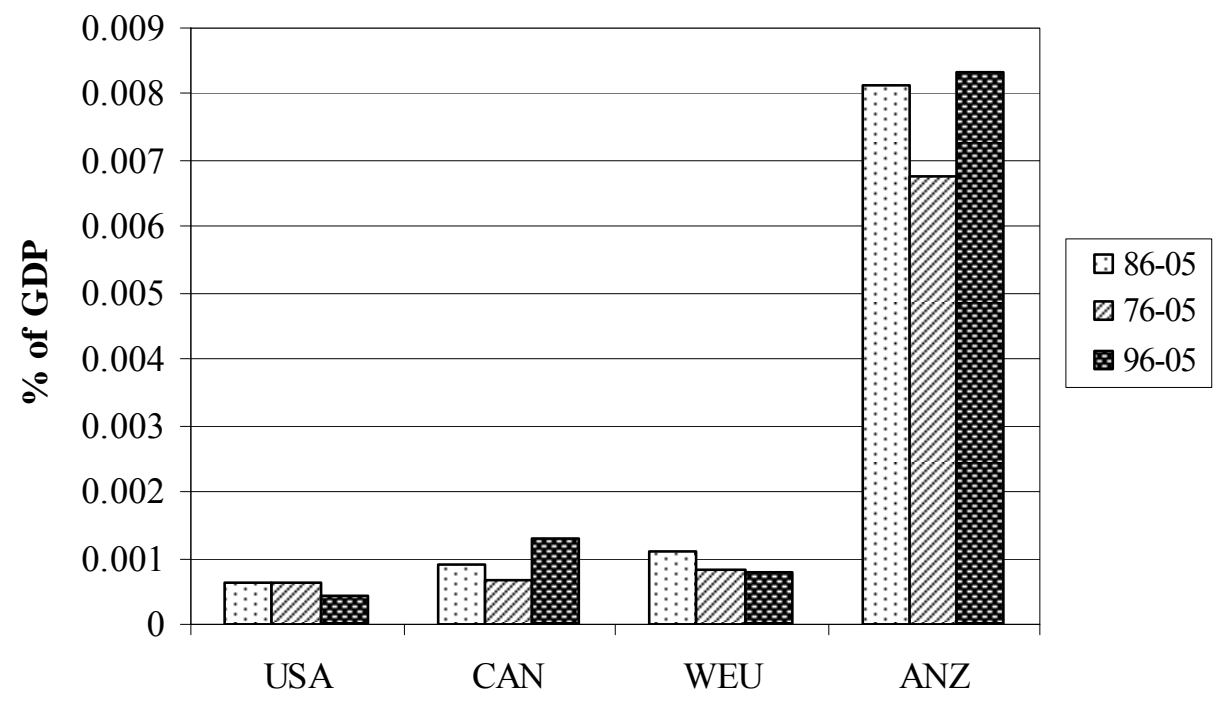


Figure 3.

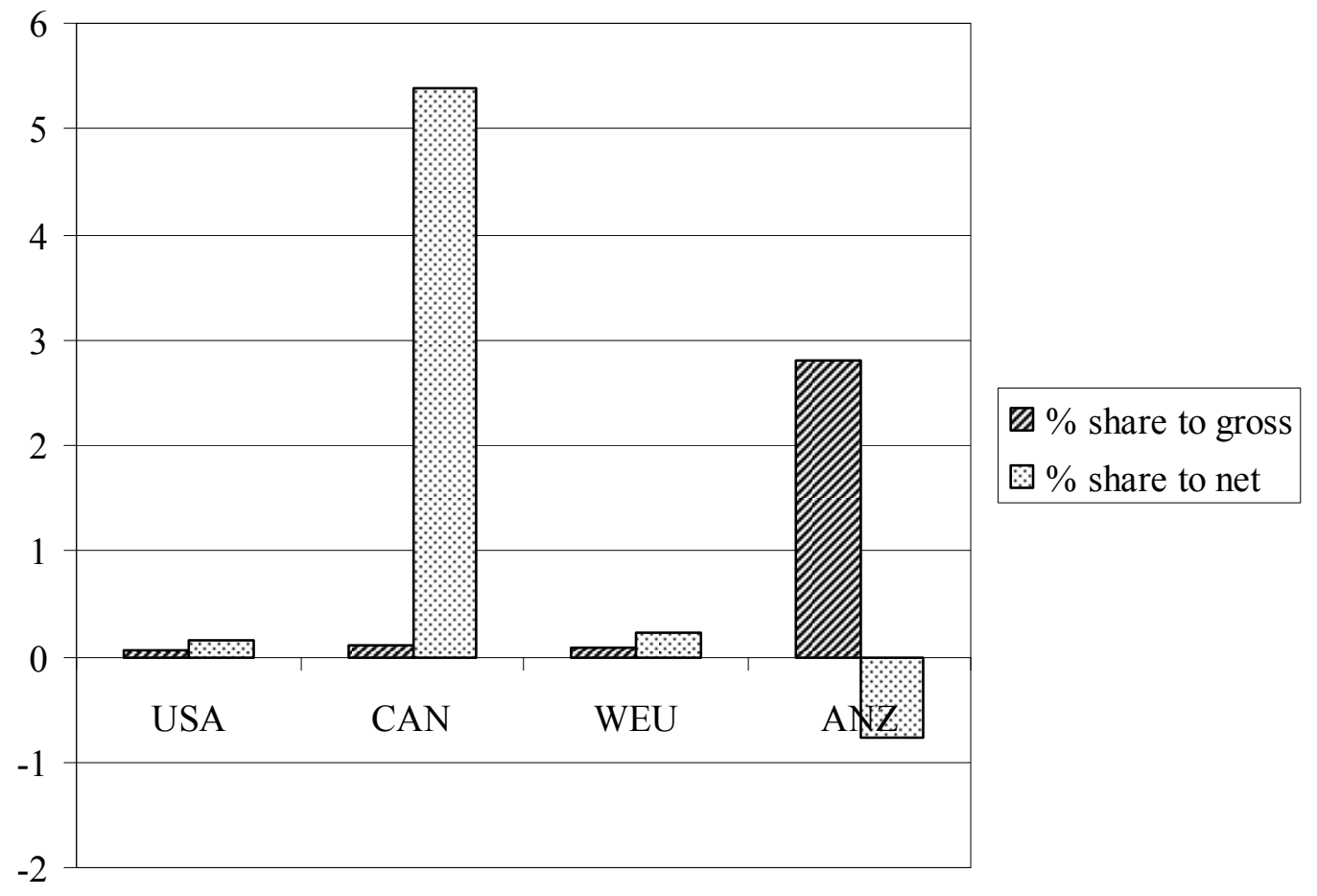




\begin{tabular}{lll}
\hline & Title/ Author(s) \\
Year & Number & ESRI Authors/ Co-authors /talicised \\
\hline
\end{tabular}

2009

The Macro-Economic Impact of Changing the Rate of Corporation Tax

Thomas Conefrey and John D. Fitz Gerald

272

The Games We Used to Play

An Application of Survival Analysis to the Sporting Life-course Pete Lunn

\section{8}

Exploring the Economic Geography of Ireland Edgar Morgenroth

Benchmarking, Social Partnership and Higher Remuneration: Wage Settling Institutions and the Public-Private Sector Wage Gap in I reland Elish Kelly, Seamus McGuinness, Philip O'Connell

A Dynamic Analysis of Household Car Ownership in Ireland Anne Nolan

The Determinants of Mode of Transport to Work in the Greater Dublin Area

Nicola Commins and Anne Nolan

Resonances from Economic Development for Current Economic Policymaking

Frances Ruane

The Impact of Wage Bargaining Regime on Firm-Level Competitiveness and Wage Inequality: The Case of I reland Seamus McGuinness, Elish Kelly and Philip O'Connell

265 Poverty in Ireland in Comparative European Perspective Christopher T. Whelan and Bertrand Maitre

A Hedonic Analysis of the Value of Rail Transport in the Greater Dublin Area Karen Mayor, Seán Lyons, David Duffy and Richard S.J. Tol

Comparing Poverty Indicators in an Enlarged EU

Christopher T. Whelan and Bertrand Maître

Fuel Poverty in Ireland: Extent, Affected Groups and Policy Issues Sue Scott, Seán Lyons, Claire Keane, Donal McCarthy and Richard S.J. Tol 
The Direct Impact of Climate Change on Regional Labour Productivity

Tord Kjellstrom, R Sari Kovats, Simon J. Lloyd, Tom Holt, Richard S.J. Tol

Damage Costs of Climate Change through Intensification of Tropical Cyclone Activities:

An Application of FUND

Daiju Narita, Richard S. J. Toland David Anthoff

Are Over-educated People Insiders or Outsiders?

A Case of J ob Search Methods and Over-education in UK Aleksander Kucel, Delma Byrne

Metrics for Aggregating the Climate Effect of Different Emissions: A Unifying Framework

Richard S.J. Tol, Terje K. Berntsen, Brian C. O'Neill, Jan S.

Fuglestvedt, Keith P. Shine, Yves Balkanski and Laszlo Makra

Intra-Union Flexibility of Non-ETS Emission Reduction

Obligations in the European Union

Richard S.J. Tol

The Economic Impact of Climate Change

Richard S.J. Tol

Measuring International Inequity Aversion

Richard S.J. Tol

Using a Census to Assess the Reliability of a National Household Survey for Migration Research: The Case of I reland

Alan Barrett and Elish Kelly

Risk Aversion, Time Preference, and the Social Cost of Carbon David Anthoff, Richard S.J. Tol and Gary W. Yohe

The Impact of a Carbon Tax on Economic Growth and Carbon Dioxide Emissions in I reland

Thomas Conefrey, John D. Fitz Gerald, Laura Malaguzzi Valeri and Richard S.J. Tol

The Distributional Implications of a Carbon Tax in I reland

Tim Callan, Sean Lyons, Susan Scott, Richard S.J. Tol and

Stefano Verde

Measuring Material Deprivation in the Enlarged EU Christopher T. Whelan, Brian Nolan and Bertrand Maître

Marginal Abatement Costs on Carbon-Dioxide Emissions: A Meta-Analysis

Onno Kuik, Luke Brander and Richard S.J. Tol 
Incorporating GHG Emission Costs in the Economic Appraisal of Projects Supported by State Development Agencies

Richard S.J. Tol and Seán Lyons

246 A Carton Tax for Ireland

Richard S.J. Tol, Tim Callan, Thomas Conefrey, John D. Fitz Gerald, Seán Lyons, Laura Malaguzzi Valeri and Susan Scott

Non-cash Benefits and the Distribution of Economic Welfare Tim Callan and Claire Keane

Scenarios of Carbon Dioxide Emissions from Aviation Karen Mayor and Richard S.J. Tol

The Effect of the Euro on Export Patterns: Empirical Evidence from Industry Data

Gavin Murphy and Iulia Siedschlag

The Economic Returns to Field of Study and Competencies Among Higher Education Graduates in Ireland Elish Kelly, Philip O'Connell and Emer Smyth

European Climate Policy and Aviation Emissions Karen Mayor and Richard S.J. Tol

Aviation and the Environment in the Context of the EU-US Open Skies Agreement Karen Mayor and Richard S.J. Tol

Yuppie Kvetch? Work-life Conflict and Social Class in Western Europe

Frances McGinnity and Emma Calvert

Immigrants and Welfare Programmes: Exploring the Interactions between I mmigrant Characteristics, Immigrant Welfare Dependence and Welfare Policy

Alan Barrett and Yvonne McCarthy

How Local is Hospital Treatment? An Exploratory Analysis of Public/Private Variation in Location of Treatment in Irish Acute Public Hospitals Jacqueline O'Reilly and Miriam M. Wiley

The Immigrant Earnings Disadvantage Across the Earnings and Skills Distributions: The Case of Immigrants from the EU's New Member States in I reland

Alan Barrett, Seamus McGuinness and Martin O'Brien

Europeanisation of Inequality and European Reference Groups

Christopher T. Whelan and Bertrand Maître 
Managing Capital Flows: Experiences from Central and Eastern Europe

Jürgen von Hagen and Iulia Siedschlag

ICT Diffusion, Innovation Systems, Globalisation and Regional Economic Dynamics: Theory and Empirical Evidence

Charlie Karlsson, Gunther Maier, Michaela Trippl, Iulia Siedschlag, Robert Owen and Gavin Murphy

Welfare and Competition Effects of Electricity Interconnection between Great Britain and Ireland

Laura Malaguzzi Valeri

Is FDI into China Crowding Out the FDI into the European Union?

Laura Resmini and Iulia Siedschlag

Estimating the Economic Cost of Disability in I reland John Cullinan, Brenda Gannon and Seán Lyons

Controlling the Cost of Controlling the Climate: The Irish

Government's Climate Change Strategy

Colm McCarthy, Sue Scott

The Impact of Climate Change on the Balanced-Growth-

Equivalent: An Application of FUND

David Anthoff, Richard S.J. Tol

Changing Returns to Education During a Boom? The Case of I reland

Seamus McGuinness, Frances McGinnity, Philip O'Connell

'New' and 'Old' Social Risks: Life Cycle and Social Class Perspectives on Social Exclusion in Ireland Christopher T. Whelan and Bertrand Maître

The Climate Preferences of Irish Tourists by Purpose of Travel Seán Lyons, Karen Mayor and Richard S.J. Tol

A Hirsch Measure for the Quality of Research Supervision, and an Illustration with Trade Economists Frances P. Ruane and Richard S.J. Tol

Environmental Accounts for the Republic of I reland: 19902005

Seán Lyons, Karen Mayor and Richard S.J. Tol

Assessing Vulnerability of Selected Sectors under Environmental Tax Reform: The issue of pricing power J. Fitz Gerald, M. Keeney and S. Scott 
Exports and Productivity - Comparable Evidence for 14 Countries

The International Study Group on Exports and Productivity

Energy-Using Appliances and Energy-Saving Features:

Determinants of Ownership in I reland

J oe O'Doherty, Seán Lyons and Richard S.J. Tol

The Public/Private Mix in I rish Acute Public Hospitals: Trends and Implications

Jacqueline O'Reilly and Miriam M. Wiley

Regret About the Timing of First Sexual Intercourse: The Role of Age and Context

Richard Layte, Hannah McGee

Determinants of Water Connection Type and Ownership of

Water-Using Appliances in I reland

J oe O'Doherty, Seán Lyons and Richard S.J. Tol

Unemployment - Stage or Stigma?

Being Unemployed During an Economic Boom

Emer Smyth

The Value of Lost Load

Richard S.J. Tol

Adolescents' Educational Attainment and School Experiences in Contemporary I reland

Merike Darmody, Selina McCoy, Emer Smyth

Acting Up or Opting Out? Truancy in Irish Secondary Schools Merike Darmody, Emer Smyth and Selina McCoy

Where do MNEs Expand Production: Location Choices of the Pharmaceutical Industry in Europe after 1992

Frances $P$. Ruane, Xiaoheng Zhang

Holiday Destinations: Understanding the Travel Choices of I rish Tourists

Seán Lyons, Karen Mayor and Richard S.J. Tol

The Effectiveness of Competition Policy and the Price-Cost Margin: Evidence from Panel Data

Patrick McCloughan, Seán Lyons and William Batt

Tax Structure and Female Labour Market Participation:

Evidence from I reland

Tim Callan, A. Van Soest, J.R. Walsh

Distributional Effects of Public Education Transfers in Seven European Countries

Tim Callan, Tim Smeeding and Panos Tsakloglou 
